\title{
Effect of irrigation on the production and volatile compounds of sweet basil cultivars (Ocimum basilicum L.)
}

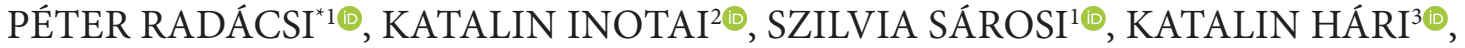 \\ KATARZYNA SEIDLER-ŁOŻYKOWSKA ${ }^{4}$, SINTAYEHU MUSIE ${ }^{1 \oplus}$, ÉVA NÉMETH \\ ZÁMBORINÉ ${ }^{1 \odot}$
}

${ }^{1}$ Department of Medicinal and Aromatic Plants

Szent István University

Villányi 29-43

H-1118 Budapest, Hungary

${ }^{2}$ NARIC, Agro-Environmental Research Institute

Department of Environmental and Applied Microbiology

Herman Ottó 15

H-1022 Budapest, Hungary

${ }^{3}$ Department of Entomology

Szent István University

Ménesi 44

H-1118 Budapest, Hungary

${ }^{4}$ Department of Botany, Breeding and Agricultural Technology of Medicinal Plants Institute of Natural Fibres and Medicinal Plants

Kolejowa 2

62-064 Plewiska, Poland

*corresponding author: tel.: +36-1-305-7251; e-mail: radacsi.peter@szie.hu

\section{Summary}

Introduction: Irrigation plays an important role in the cultivation of medicinal plants. There is a lack of information on intraspecific variability of reactions to the effect of drought.

Objective: The aim of the current study was to test the effect of irrigation on four sweet basil (Ocimum basilicum L.) cultivars ('Genovese', 'Kasia', 'Keskenylevelü', 'Wala').

Methods: In an open field experiment irrigated and non-irrigated treatments were set. Plants were harvested in full flowering stage. Before the harvest, the stomatal conductance and chlorophyll content were meas- 
ured. The production-related parameters were recorded. In the plant material the glandular hair density, essential oil content and composition (GC-MS) and volatile composition (SPME-GC-MS) were identified.

Results: Stomatal conductance of the irrigated plants was 2.5-4.5 times higher than in the non-irrigated ones. The chlorophyll content showed only slight changes. The irrigation had a positive effect on the production. The leaf to stem ratio was not modified by the watering. Irrigation negatively influenced the glandular hair density and the EO content, however it increased the EO yield by $40-129 \%$, depending on the cultivar. Significant compositional changes were registered only in the EO of cultivar 'Kasia' for linalool, 1,8-cineole and tau-cadinole ratios.

Conclusion: Irrigation increases the biomass and EO yield of basil while the composition of the EO is mostly unchanged. Only slight differences were observed among the cultivars.

Key words: cultivar, drought, essential oil, Lamiaceae, water supply, stress

Słowa kluczowe: odmiana, susza, olejek eteryczny, Lamiaceae, dostarczanie wody, stres

\section{INTRODUCTION}

Sweet basil (Ocimum basilicum L.) is a well-known medicinal and aromatic plant from the Lamiaceae family. Several applications of the species have been described, including phytotherapy, culinary, and cosmetic uses - and even new areas (e.g. pest control). Sweet basil has diverse morphological characteristics. The size, shape and colour of the leaves and flowers as well as the smell are highly variable. Most therapeutic applications are related to the essential oil (EO) accumulating in the glandular hairs on the surface of leaves and flowers. The EO content varies between $0.2-5.2 \mathrm{ml}^{100 \mathrm{~g}^{-1}} \mathrm{dry}$ mass (d.m.) [1, 2] and almost 140 components have been identified in the $\mathrm{EO}$ of O. basilicum [3]. Based on these components, several chemotypes were described, e.g. linalool, estragole, eugenol, and methyl cinnamate $[2,4]$. Linalool is the most common EO component of the basil cultivars. Its ratio varies in 'Genovese' between 54-66\% [5-7] while in 'Kasia' and 'Wala' it ranges from 62 to $72 \%$ and from 55 to $66 \%$, respectively $[8,9]$.

Basil, native to subtropical areas, prefers humus rich, well drained loamy or sandy-loamy soils. Although in Central and Southern Europe most frequent limiting factor of the biomass production is the amount of precipitation, there are no adequate data for the optimal water supply. The results regarding the effects of water supply on EO bearing plants are often contradictory, indicating that this question calls for a complex scientific answer.

Several publications can be found concerning the effect of drought stress or the effect of irrigation on medicinal and aromatic plants [7, 1012]. Relatively few of them used sweet basil as the model species: Khalid [13] proved that for sweet basil, maintaining $75 \%$ of field water capacity (FC) is optimal. Both higher $(100,125 \%)$ and lower (50\%) field capacities decreased the biomass production and EO yield. However, the highest EO concentration was detected under drought conditions ( $50 \% \mathrm{FC})$. It is reported that compared to the control (30\% water deficiency) the severe water stress ( $70 \%$ water deficiency) decreased the plant height, number of shoots and leaves, and fresh and dry mass of 'Thai Magic' cultivar of sweet basil [14]. A similar effect was described by Ade-Ademilua et al. [15], who observed that shortage of water decreased the plant height and negatively influenced the fresh and dry mass as well as leaf size. It was also found that water shortage combined with shortage of light influenced the biomass more intensively. In previous studies, we found that water shortage decreased the relative water content (from $96.7 \%$ to $77.5 \%$ ) and the water potential (from $-0.48 \mathrm{MPa}$ to $-1.05 \mathrm{MPa}$ ) in leaves of 'Genovese' cultivar. Reduced dry mass (10.0 g plant $\left.^{-1}\right)$ was observed under $30 \%$ soil water capacity compared to the control (15.2 $\left.\mathrm{g} \mathrm{plant}^{-1}\right)$. The EO concentration and yield showed the opposite tendency. The EO concentration of the leaves increased in parallel with the rising water deficit

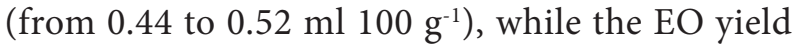
decreased (from $0.07 \mathrm{ml} \mathrm{plant}^{-1}$ to $0.05 \mathrm{ml} \mathrm{plant}^{-1}$ ) [7]. In the case of purple leaved basil, a similar reaction was found: $125 \%$ of field capacity induced the highest fresh and dry mass compared to $50 \%$ and $75 \%$ field capacity treatments. Nevertheless, the EO content showed higher values under extreme field capacities (50\% and 125\%) compared to the $100 \%$ of field capacity [16]. 
It can be concluded that in spite of its popularity as an aromatic herb, the available scientific information on the water requirement of basil is limited and contradictory. In addition, there is hardly any data on specific behavior of varieties, as all the abovementioned studies always included only a single accession of sweet basil. The goal of our investigations was to get reliable data on the intraspecific responses of basil to different water supplies, in terms of biomass production and volatile components.

\section{MATERIALS AND METHODS}

\section{Site description and experimental design}

Open field experiment was set in the experimental field of Szent István University in BudapestSoroksár (Hungary) in 2009. Seeds of O. basilicum L. 'Genovese' and 'Keskenylevelü' cultivars were selected from the gene bank of the Department of Medicinal and Aromatic Plants, while the seeds of 'Kasia' and 'Wala' were obtained from the Institute of Natural Fibres and Medicinal Plants (Poznań, Poland). Under greenhouse conditions, seeds were sown into seed trays $(27 \times 57 \mathrm{~cm})$ in the middle of March. Small pots (0.1 l) were used to transplant the two leaves seedlings. In the second part of May (May $\left.22^{\text {nd }}\right)$, thirty plants were designated for each treatment and planted in plots at a $50 \times 30 \mathrm{~cm}$ distance ( 1 watered and 1 non-irrigated control plot). The soil characteristics are summarized in table 1.

Table 1.

Main soil characteristics of the experimental plots (Budapest 2009)

\begin{tabular}{ccccccc}
\hline $\mathrm{pH}_{\mathrm{H} 2 \mathrm{O}}$ & $\begin{array}{c}\text { Salt } \\
{[\%]}\end{array}$ & $\begin{array}{c}\text { Humus } \\
{[\%]}\end{array}$ & $\begin{array}{c}\mathrm{NO}_{3}-\mathrm{N} \\
{\left[\mathrm{mg} \mathrm{kg}^{-1}\right]}\end{array}$ & $\begin{array}{c}\mathrm{P}_{2} \mathrm{O}_{5} \\
{\left[\mathrm{mg} \mathrm{kg}^{-1}\right]}\end{array}$ & $\begin{array}{c}\mathrm{K}_{2} \mathrm{O} \\
{\left[\mathrm{mg} \mathrm{kg}^{-1}\right]}\end{array}$ & $\begin{array}{c}\mathrm{Ca} \\
{[\%]}\end{array}$ \\
\hline 6.49 & 0.04 & 1.17 & 1.24 & 29.001 & 36.70 & 0.49 \\
\hline $\begin{array}{c}\mathrm{Mg} \\
{\left[\mathrm{mg} \mathrm{kg}^{-1}\right]}\end{array}$ & $\begin{array}{c}\mathrm{Fe} \\
{\left[\mathrm{mg} \mathrm{kg}^{-1}\right]}\end{array}$ & $\begin{array}{c}\mathrm{Mn} \\
{\left[\mathrm{mg} \mathrm{kg}^{-1}\right]}\end{array}$ & $\begin{array}{c}\mathrm{Zn} \\
{\left[\mathrm{mg} \mathrm{kg}^{-1}\right]}\end{array}$ & $\begin{array}{c}\mathrm{Cu} \\
{\left[\mathrm{mg} \mathrm{kg}^{-1}\right]}\end{array}$ & $\begin{array}{c}\mathrm{CaCO}_{3} \\
{[\%]}\end{array}$ & \\
\hline 53.00 & 109.00 & 37.80 & 1.73 & 3.47 & $<1.00$ & \\
\hline
\end{tabular}

Watered (W) and non-irrigated control (C) treatments were applied to evaluate the effect of water supply. The non-irrigated plots got only natural precipitation: during the whole experiment there was only $177 \mathrm{~mm}$ of natural precipitation. The irrigated plots were watered with $20 \mathrm{~mm}$ water twice a week, except when the natural precipitation reached this amount. A spraying irrigation system equiped with water meter was used to check the amount of irrigation water.
Between the plots one meter isolation distance was kept. The climatic parameters of the experimental period are indicated in table 2 . Based on our former experiences the soil nutrient level for basil cultivation was sufficient. No additional nutrient supply or chemical plant protection was applied.

Table 2.

Meteorological data of the experimental field (Budapest 2009)

\begin{tabular}{lllllllll}
\hline Parameter & April May June July & August & $\begin{array}{c}\text { Sep- } \\
\text { tember }\end{array}$ & $\begin{array}{c}\text { Average/ } \\
\text { Summary }\end{array}$ \\
\hline $\begin{array}{l}\text { Tempera- } \\
\left.\text { ture [ }{ }^{\circ} \mathrm{C}\right]\end{array}$ & 12.7 & 15.1 & 16.7 & 20.2 & 19.7 & 16.3 & 16.8 \\
\hline $\begin{array}{l}\text { Precipita- } \\
\text { tion [mm] }\end{array}$ & 3.4 & 20.2 & 117.4 & 43.8 & 25.6 & 26.8 & 237.2 \\
\hline
\end{tabular}

\section{Chlorophyll content (SPAD)}

SPAD 502Plus (Konica Minolta Inc., Japan) was used to determine the chlorophyll content of basil leaves. Samples were taken at the $3^{\text {rd }}$ internodes under the top of the shoots, a day before harvesting. Eight samplings were made on each leaf and their mean was calculated. This measurement was repeated on 9 individual plants for each treatment [17].

\section{Stomatal conductance}

Stomatal conductance of the leaves was determined with an AP4 porometer (Delta-T Devices Ltd., United Kingdom). Readings were taken at the $3^{\text {rd }}$ and $4^{\text {th }}$ internode under the inflorescence in the late morning hours, two days after the last irrigation. Eighteen replications per treatment were taken.

\section{Determination of production-related parameters}

Ten individuals were selected at random. Just before harvesting, plant height was measured from ground level to the tip of the shoots, and largest bush diameter was also recorded. Plants were harvested at the full flowering stage (majority of flowers opened) at the beginning of August (August $4^{\text {th }}$ ). Immediately, after harvesting, ten plant individuals were measured and the fresh mass was determined. Natural drying was carried out in shade till they had constant weight, and then the dry mass was registered. After the leaves and flowers were separated from 
the dry stems the leaf-stem ratio (10 individuals per treatment) was calculated. Further laboratory analyses were carried out in three replicates/treatments, on samples containing 3 individuals each. For the laboratory analysis, the stems were excluded.

\section{Determination of essential oil related parameters}

\section{Glandular hair density}

The glandular hair density measurement was carried out by the modified method of [18]. For investigations on glandular hairs, samples were taken from the leaf blade of the $3^{\text {rd }}$ internode from the top. Circles of $4.0 \mathrm{~mm}$ diameter were cut out from the central part of leaf blade. The main vein of the leaf was excluded from the sampling. The number of glandular peltate hairs on the abaxial surface of these blade samples was counted under a stereomicroscope (type BMS 74959). Ten replicates per treatment were carried out.

\section{Essential oil content}

Dry leaves and flowers (with the exception of stems) were used to determine the $\mathrm{EO}$ concentration. Three replications per treatment were applied, according to the Pharmacopoeia Hungarica [19]. Clevengertype apparatus was used.

\section{Headspace and essential oil composition}

Volatile components of the aerial parts (Headspace - HS) were identified by a Solid Phase Microextraction (SPME) method, according to the method of [17]. Fresh shoot samples ( $2.5 \mathrm{~g}$ ) were taken one day before harvest and the plant material was put into a $20 \mathrm{ml}$ screw vial which was hermetically sealed. After 30 minutes incubation at $19^{\circ} \mathrm{C}$ sampling was carried out through the septum for 10 minutes. The fibre (Supelco, $100 \mu \mathrm{m}$ polydimethylsiloxane-covered fibre) was held in the inlet of GC for $33 \mathrm{sec}-$ onds. The SPME analysis was carried out in 3 replications per treatment.

The compositions of the EO and HS were determined by the GC-MS method [20]. GC analysis was carried out using an Agilent Technologies $6890 \mathrm{~N}$ instrument equipped with an HP-5MS capillary column (30 m x $0.25 \mathrm{~mm}, 0.25 \mu \mathrm{m}$ film thickness), with the following temperature program: initial temperature $60^{\circ} \mathrm{C}$, heating at a rate of $3^{\circ} \mathrm{C} / \mathrm{min}$ up to $240^{\circ} \mathrm{C}$; the final temperature was maintained for $5 \mathrm{~min}$; injector and detector temperatures: $250^{\circ} \mathrm{C}$; carrier gas: helium (constant flow rate: $1 \mathrm{ml} \mathrm{min}^{-1}$ ); split ratio: 30:1, injection volume $0.2 \mu \mathrm{l}(10 \%$, n-hexane). The proportions of individual compounds were expressed as total area percentages. For the identification of components, the above-mentioned equipment was used with an Agilent Technologies MS 5975 detector. Ionization energy was $70 \mathrm{eV}$. The mass spectra were recorded in full scan mode, which revealed the total ion current (TIC) chromatograms. A mixture of aliphatic hydrocarbons (C9-C23) in n-hexane was injected to calculate the linear retention indices using the generalized equation of [21]. The linear retention indices (LRI) and mass spectra were compared with commercial ones (NIST, Wiley) and home-made library mass spectra built up from data obtained from standard (Sigma/Aldrich) pure compounds. SPME and GC samples were repeated three times.

\section{Statistical analysis}

The results were analysed with the IBM SPSS Statistics 19 software. The results are given as mean \pm standard deviation (SD), and one-way analysis of variance (ANOVA) with one or two factors was used for comparison of more than two means. Normality of the residuals was justified by the KolmogorovSmirnov method. Homogeneity of variances was tested by Levene's method. Treatments were separated by Games-Howell's or Tukey's post hoc tests, depending on whether homogeneity assumption was violated or not.

Ethical approval: The conducted research is not related to either human or animal use.

\section{RESULTS}

Irrigation affected most of the parameters of basil that we measured. The stomatal conductance of all cultivars increased significantly, if additional water supply was applied (tab. 3). It means that as an effect of irrigation, plants could transpirate 4-5-fold more water than the non-irrigated control ones. The conductance values varied between 67 and $419 \mathrm{mmol}$ $\mathrm{m}^{-2} \mathrm{~s}^{-1}$. Highest results were measured in 'Genovese' cultivar, followed by 'Keskenylevelü', 'Kasia' and finally 'Wala.' The last three varieties were not statistically different from each other. 
Irrigation had a low impact on chlorophyll content (SPAD values); only in 'Kasia' did the limited water supply decrease the values significantly (tab. 3). At the same time, the cultivars had significant effect on SPAD values.

Water supply enhanced almost all productionrelated parameters of sweet basil. Irrigation had a positive effect on the plant height, bush diameter, and fresh and dry mass of all investigated cultivars. Irrigated plants had 5-10 $\mathrm{cm}$ greater plant height and $8-10 \mathrm{~cm}$ wider bush diameter, as compared to the control (tab. 3). The cultivars showed significant differences in plant height and bush diameter: 'Keskenylevelü' had the highest, while 'Genovese' had the widest plants. In general, the yield of all cultivars increased when additional water was applied (tab. 3). In the irrigated plots, the fresh mass of plants varied between 181 and $201 \mathrm{~g}$ plant $^{-1}$, while in the control plots it was between 76 and 102 g plant $^{-1}$. Similar tendency was observed in the dry mass as well: the watered plants produced almost twice as high drug yield as the non-irrigated controls. Among the cultivars, 'Kasia' produced the highest fresh and dry mass, followed by 'Keskenylevelü', while 'Genovese' and 'Wala' had lower production. The ratio of leaves and flowers was not influenced by the irrigation; values varied between $56.4 \%$ and $65.6 \%$. However, differences were observable within the cultivars. 'Genovese' and 'Wala' had significantly higher leaf ratio than 'Kasia' and 'Keskenylevelü'. In practice, this means that the first two cultivars had almost 3-10\% higher ratio of the useful plant organs than the last two.

The effect of irrigation on the EO-related parameters is presented in table 4 . The average values of the EO content of investigated basil cultivars decreased. If irrigation was applied, the only exception was 'Wala' variety, where a slight, insignificant increase was observed. The most notable decrease was measured in 'Keskenylevelü', where the EO content decreased by more than $30 \%$. The accumulation level of EO was mainly determined by the cultivar. Significantly, the highest average EO content was detected in 'Kasia' (2.25\%), followed by 'Wala' (1.21\%), while the other two showed a lower accumulation level: 'Genovese' (0.82\%) and 'Keskenylevelü' (0.69\%). The statistical analysis showed the interaction between watering and cultivar $(p=0.003)$. Compared to the essential oil concentration, in the essential oil yield $\left(\mathrm{ml} \mathrm{plant}^{-1}\right)$ a reverse tendency was observed: in all cultivars it increased as an effect of irrigation.

In the Lamiaceae family, the essential oil is accumulated in the glandular hairs. The density of these hairs was not significantly influenced by the water supply (tab. 4). However, differences were found among the cultivars: 'Genovese' and 'Kasia' exhibited significantly greater glandular hair density than 'Keskenylevelü' and 'Wala' the latter showing only half of 'Kasia's' glandular hair density.

Table 3.

Effect of irrigation on the physiological and production related parameters of different sweet basil cultivars (Budapest 2009)

\begin{tabular}{|c|c|c|c|c|c|c|c|c|}
\hline \multirow{2}{*}{ Parameter } & \multicolumn{2}{|c|}{ 'Genovese' } & \multicolumn{2}{|c|}{ 'Kasia' } & \multicolumn{2}{|c|}{ 'Keskenylevelü' } & \multicolumn{2}{|c|}{ 'Wala' } \\
\hline & $\mathrm{W}$ & $\mathrm{C}$ & $\mathrm{W}$ & $\mathrm{C}$ & $\mathrm{W}$ & $\mathrm{C}$ & $\mathrm{W}$ & $\mathrm{C}$ \\
\hline \multirow{2}{*}{$\begin{array}{l}\text { SPAD } \\
\text { chlorophyll }\end{array}$} & $39.9 \pm 1.6$ & $37.2 \pm 2.7$ & $28.6 \pm 0.7$ & $32.9 \pm 3.3$ & $36.7 \pm 4.1$ & $38.5 \pm 3.9$ & $36.5 \pm 4.4$ & $34.7 \pm 2.2$ \\
\hline & $\mathrm{A} \mathrm{a}$ & $\mathrm{A} \mathrm{a}$ & $\mathrm{B} \mathrm{b}$ & $\mathrm{A} \mathrm{a}$ & $\mathrm{A} \mathrm{a}$ & $\mathrm{Ab}$ & $\mathrm{A} \mathrm{a}$ & $\mathrm{Ab}$ \\
\hline \multirow{2}{*}{$\begin{array}{l}\text { Stomatal } \\
\text { conductance }\end{array}$} & $419.7 \pm 106.1$ & $149.2 \pm 66.5$ & $304.3 \pm 99.9$ & $67.7 \pm 39.3$ & $349.4 \pm 63.1$ & $85.2 \pm 53.0$ & $289.1 \pm 39.3$ & $63.1 \pm 39.3$ \\
\hline & $\mathrm{A} \mathrm{a}$ & $\mathrm{B} \mathrm{a}$ & $\mathrm{Ab}$ & $\mathrm{B} \mathrm{b}$ & $\mathrm{Ab}$ & $\mathrm{B} \mathrm{b}$ & $\mathrm{Ab}$ & $\mathrm{B} \mathrm{b}$ \\
\hline \multirow{2}{*}{$\begin{array}{l}\text { Plant height } \\
{[\mathrm{cm}]}\end{array}$} & $43.3 \pm 2.9$ & $38.7 \pm 4.5$ & $47.8 \pm 2.9$ & $42.4 \pm 3.2$ & $51.4 \pm 2.8$ & $43.8 \pm 6.3$ & $45.8 \pm 2.3$ & $38.1 \pm 2.6$ \\
\hline & A c & $\mathrm{B} a b$ & $\mathrm{~A} a b$ & $\mathrm{~B} a b$ & $\mathrm{~A} \mathrm{a}$ & $\mathrm{B} \mathrm{a}$ & $\mathrm{A} \mathrm{bc}$ & $\mathrm{B} \mathrm{b}$ \\
\hline \multirow{2}{*}{$\begin{array}{l}\text { Bush diamater } \\
{[\mathrm{cm}]}\end{array}$} & $40.4 \pm 3.0$ & $31.2 \pm 4.7$ & $36.4 \pm 3.3$ & $28.9 \pm 3.8$ & $40.0 \pm 7.3$ & $31.7 \pm 4.8$ & $37.5 \pm 1.6$ & $27.5 \pm 2.8$ \\
\hline & $\mathrm{A} \mathrm{a}$ & $\mathrm{B}$ ab & $\mathrm{A} \mathrm{a}$ & $\mathrm{B}$ ab & $\mathrm{A} \mathrm{a}$ & $\mathrm{B} \mathrm{a}$ & $\mathrm{A} \mathrm{a}$ & $\mathrm{B} \mathrm{b}$ \\
\hline \multirow{2}{*}{$\begin{array}{l}\text { Fresh mass } \\
\text { [g plant }^{-1} \text { ] }\end{array}$} & $162.5 \pm 31.8$ & $86.0 \pm 26.5$ & $201.9 \pm 47.3$ & $102.2 \pm 26.8$ & $195.3 \pm 47.8$ & $100.7 \pm 32.6$ & $181.4 \pm 40.9$ & $76.6 \pm 10.9$ \\
\hline & $\mathrm{Ab}$ & $\mathrm{B}$ ab & $\mathrm{A}$ a & $\mathrm{B} \mathrm{a}$ & $\mathrm{A} a \mathrm{~b}$ & $\mathrm{~B}$ ab & $\mathrm{A} a b$ & $\mathrm{~B} \mathrm{~b}$ \\
\hline \multirow{2}{*}{$\begin{array}{l}\text { Dry mass } \\
\text { [g plant }^{-1} \text { ] }\end{array}$} & $38.0 \pm 8.0$ & $20.9 \pm 6.9$ & $41.7 \pm 11.8$ & $26.8 \pm 3.3$ & $40.6 \pm 6.7$ & $19.7 \pm 5.3$ & $30.0 \pm 7.8$ & $13.4 \pm 3.3$ \\
\hline & $\mathrm{A} \mathrm{ab}$ & $\mathrm{B} \mathrm{b}$ & $\mathrm{A} \mathrm{a}$ & $\mathrm{B}$ a & $\mathrm{A} \mathrm{a}$ & $\mathrm{B} \mathrm{b}$ & $\mathrm{Ab}$ & $\mathrm{B} \mathrm{C}$ \\
\hline \multirow{2}{*}{ Leaf ratio [\%] } & $65.6 \pm 1.6$ & $63.7 \pm 2.6$ & $55.9 \pm 3.9$ & $59.8 \pm 4.4$ & $56.4 \pm 3.6$ & $56.1 \pm 7.0$ & $61.7 \pm 4.6$ & $63.6 \pm 6.2$ \\
\hline & $\mathrm{a}$ & $\mathrm{a}$ & b & $\mathrm{ab}$ & $\mathrm{b}$ & $\mathrm{b}$ & $\mathrm{a}$ & $\mathrm{a}$ \\
\hline
\end{tabular}

Values are the mean $\pm S D$. Lower case letters in rows represent significant differences between cultivars in the same treatment and capital letters in rows represent significant differences between treatments at the same cultivar, according to the Games-Howell or Tukey test at $\alpha=0.05, \mathrm{~W}$ - watered, $\mathrm{C}$ - control 
Table 4.

Effect of water supply on the essential oil related parameters of sweet basil cultivars (Budapest 2009)

\begin{tabular}{|c|c|c|c|c|c|c|c|c|}
\hline \multirow{2}{*}{ Measured parameter } & \multicolumn{2}{|c|}{ 'Genovese' } & \multicolumn{2}{|c|}{ 'Kasia' } & \multicolumn{2}{|c|}{ 'Keskenylevelü' } & \multicolumn{2}{|c|}{ 'Wala' } \\
\hline & $\mathrm{W}$ & $\mathrm{C}$ & $\mathrm{W}$ & $\mathrm{C}$ & $\mathrm{W}$ & $\mathrm{C}$ & $\mathrm{W}$ & $\mathrm{C}$ \\
\hline $\begin{array}{l}\text { Essential oil conten } \\
{\left[\mathrm{ml} 100 \mathrm{~g}^{-1} \mathrm{dm}\right]}\end{array}$ & $\begin{array}{c}0.757 \pm 0.054 \\
\text { A c }\end{array}$ & $\begin{array}{c}0.878 \pm 0.055 \\
\text { A c }\end{array}$ & $\begin{array}{c}2.139 \pm 0.032 \\
\mathrm{~B} \mathrm{a}\end{array}$ & $\begin{array}{c}2.368 \pm 0.085 \\
\mathrm{~A} \mathrm{a}\end{array}$ & $\begin{array}{c}0.564 \pm 0.032 \\
\text { B d }\end{array}$ & $\begin{array}{c}0.809 \pm 0.064 \\
\text { A c }\end{array}$ & $\begin{array}{c}1.231 \pm 0.093 \\
\mathrm{~A} \mathrm{~b}\end{array}$ & $\begin{array}{c}1.198 \pm 0.012 \\
\mathrm{~A} \mathrm{~b}\end{array}$ \\
\hline $\begin{array}{l}\text { Essential oil yield } \\
{\left[\mathrm{ml} \mathrm{plant}^{-1}\right]}\end{array}$ & 0.288 & 0.184 & 0.891 & 0.636 & 0.229 & 0.159 & 0.369 & 0.161 \\
\hline $\begin{array}{l}\text { Glandular hair density } \\
{\left[\mathrm{pc} 100 \mathrm{~mm}^{-2}\right]}\end{array}$ & $\begin{array}{c}42.08 \pm 8.86 \\
\mathrm{a}\end{array}$ & $\begin{array}{c}43.40 \pm 9.08 \\
\mathrm{a}\end{array}$ & $\begin{array}{c}28.93 \pm 11.23 \\
b\end{array}$ & $\begin{array}{c}36.56 \pm 8.72 \\
\mathrm{a}\end{array}$ & $\begin{array}{c}18.80 \pm 8.88 \\
\mathrm{~b}\end{array}$ & $\begin{array}{c}20.38 \pm 5.68 \\
b\end{array}$ & $\begin{array}{c}18.54 \pm 5.39 \\
\mathrm{~b}\end{array}$ & $\begin{array}{c}18.41 \pm 4.90 \\
\mathrm{~b}\end{array}$ \\
\hline
\end{tabular}

Values are the mean \pm SD. Lower case letters in rows represent significant differences between cultivars in the same treatment and capital letters in rows represent significant differences between treatments at the same cultivar, according to the Games-Howell or Tukey test at $\alpha=0.05, \mathrm{~W}$ - watered, $\mathrm{C}$ - control

The water supply had only a slight effect on the EO composition (tab. 5). In the EO, 32 compounds were identified. Linalool was found to be the main component in all investigated samples: its ratio varied between 52 and $70 \%$. A significant difference due to the reduced water supply was found only in the cultivar 'Kasia, where the linalool ratio decreased by more than $20 \%$. In other three cultivars, the regular water supply increased the linalool ratio, however, these changes were not significant. Larger components of the samples were tau-cadinol (5.6$11.6 \%), 1.8$-cineole $(0.8-8.6 \%)$ and germacrene-D (1.3-4.1\%). Among them, irrigation significantly altered the ratios of 1,8-cineole and tau-cadinol only in 'Kasia', in which an increase was detected.

In general, the monoterpenes were present in the EO samples between 64 and $88 \%$, while the sesquiterpenes presented between 12 and 32\%. Their ratio did not change with watering, except from 'Kasia', where irrigation decreased the ratio of monoterpenes by $22 \%$.

The HS analysis showed remarkable differences in the composition, as opposed to the EO (tab. 6). Nevertheless, the water supply did not modify the HS volatile composition. Linalool was the main component in all cultivars. Its ratio varied between $49 \%$ and 76\%. 'Genovese' had significantly lower linalool content, as compared to the others. The second largest component was 1,8-cineole in 'Genovese' (10.9$12.3 \%$ ), while in other cultivars this component was present in lower percentages. The germacrene-D content was very similar in all cultivars (5.1-6.6\%). No oxygenated sesquiterpenes were detectable in the HS composition.

Table 5.

The effect of water supply on the essential oil composition of sweet basil cultivars (Budapest 2009)

\begin{tabular}{|c|c|c|c|c|c|c|c|c|c|c|}
\hline \multirow{3}{*}{ Component } & \multirow{3}{*}{$\mathrm{RT}$} & \multirow{3}{*}{ LRI } & \multicolumn{8}{|c|}{ Essential oil composition } \\
\hline & & & \multicolumn{2}{|c|}{ 'Genovese' } & \multicolumn{2}{|c|}{ 'Kasia' } & \multicolumn{2}{|c|}{ 'Keskenylevelü' } & \multicolumn{2}{|c|}{ 'Wala' } \\
\hline & & & $\mathrm{W}$ & $\mathrm{C}$ & $\mathrm{W}$ & $\mathrm{C}$ & $\mathrm{W}$ & $\mathrm{C}$ & $\mathrm{W}$ & $\mathrm{C}$ \\
\hline Sabinene & 6.52 & 976 & - & 0.10 & 0.05 & - & - & - & - & - \\
\hline$\beta$-Pinene & 6.64 & 981 & 0.25 & 0.27 & 0.26 & - & - & - & - & - \\
\hline$\beta$-Myrcene & 6.99 & 995 & 0.18 & 0.24 & 0.21 & - & - & - & - & - \\
\hline Limonene & 8.19 & 1031 & 0.17 & 0.20 & 0.19 & - & - & - & - & - \\
\hline 1,8-Cineole & 8.77 & 1048 & $6.53^{\mathrm{Aa}}$ & $8.57^{\mathrm{Aa}}$ & $7.55^{\mathrm{Ab}}$ & $1.08^{\mathrm{Bb}}$ & $0.80^{\mathrm{Ab}}$ & $1.42^{\mathrm{Ab}}$ & $3.23^{\mathrm{Ab}}$ & $2.87^{\mathrm{Ab}}$ \\
\hline (E)-Ocimene & 8.85 & 1050 & - & 0.10 & 0.05 & - & - & - & - & - \\
\hline Linalool & 11.17 & 1112 & $54.21^{\mathrm{Ab}}$ & $52.52^{\mathrm{Ab}}$ & $53.37^{\text {ва }}$ & $76.96^{\mathrm{Aa}}$ & $70.14^{\mathrm{Aa}}$ & $69.12^{\mathrm{Aa}}$ & $62.89^{\mathrm{Aa}}$ & $62.25^{\mathrm{Aa}}$ \\
\hline Camphor & 13.1 & 1151 & - & 0.18 & 0.09 & 0.33 & - & 0.32 & - & - \\
\hline Terpinen-4-ol & 14.21 & 1174 & - & - & - & 0.29 & - & 2.30 & 0.54 & 0.21 \\
\hline$\alpha$-Terpineole & 14.55 & 1189 & 0.55 & 0.86 & 0.71 & - & - & - & 0.25 & 0.19 \\
\hline Tstragole & 14.85 & 1196 & - & - & - & - & - & - & 1.18 & - \\
\hline
\end{tabular}


Table 5. (continued)

\begin{tabular}{|c|c|c|c|c|c|c|c|c|c|c|}
\hline \multirow{3}{*}{ Component } & \multirow{3}{*}{ RT } & \multirow{3}{*}{ LRI } & \multicolumn{8}{|c|}{ Essential oil composition } \\
\hline & & & \multicolumn{2}{|c|}{ 'Genovese' } & \multicolumn{2}{|c|}{ 'Kasia' } & \multicolumn{2}{|c|}{ 'Keskenylevelü' } & \multicolumn{2}{|c|}{ 'Wala' } \\
\hline & & & $\mathrm{W}$ & $\mathrm{C}$ & $\mathrm{W}$ & $\mathrm{C}$ & $\mathrm{W}$ & $\mathrm{C}$ & $\mathrm{W}$ & $\mathrm{C}$ \\
\hline Linalyl acetate & 17.65 & 1269 & - & - & - & 8.73 & - & - & 9.60 & 11.29 \\
\hline Isobornyl acetate & 18.64 & 1300 & 3.21 & 3.77 & 3.49 & - & 0.69 & 0.78 & 0.31 & - \\
\hline Eugenol & 21.67 & 1373 & 1.12 & 2.08 & 1.60 & - & 1.12 & 2.01 & - & - \\
\hline Geranyl-acetate & 22.43 & 1388 & - & - & - & - & - & - & 1.07 & 1.33 \\
\hline$\beta$-Elemene & 22.65 & 1397 & 1.08 & 0.80 & 0.94 & 0.52 & 1.05 & 1.01 & 0.32 & 0.53 \\
\hline$\beta$-Caryophyllene & 23.68 & 1423 & - & 0.17 & 0.09 & - & - & - & - & - \\
\hline trans $-\alpha$-Bergamotene & 24.36 & 1440 & 1.75 & 2.27 & 2.01 & - & 1.26 & 0.81 & - & - \\
\hline$\alpha$-Guaiene & 24.45 & 1442 & 1.40 & 1.07 & 1.24 & 0.31 & 1.32 & - & 0.16 & 0.28 \\
\hline Gromadendrene & 24.58 & 1442 & - & - & - & - & - & 1.26 & - & - \\
\hline$\alpha$-Humulene & 25.07 & 1458 & 1.13 & 0.91 & 1.02 & - & 0.68 & 0.73 & - & - \\
\hline Alloaromadendrene & 25.39 & 1462 & 0.37 & 0.39 & 0.38 & - & 0.22 & - & 0.23 & 0.33 \\
\hline Germacren-D & 26.18 & 1486 & $4.11^{\mathrm{Aa}}$ & $2.82^{\mathrm{Aa}}$ & $3.47^{\mathrm{Aa}}$ & $1.32^{\mathrm{Aa}}$ & $2.90^{\mathrm{Aa}}$ & $2.70^{\mathrm{Aa}}$ & $2.77^{\mathrm{Aa}}$ & $2.81^{\mathrm{Aa}}$ \\
\hline$\beta$-Selinene & 26.38 & 1491 & - & - & - & - & - & - & 0.55 & 0.43 \\
\hline Bicyclogermacrene & 26.81 & 1501 & 1.45 & 1.11 & 1.28 & 0.39 & 0.29 & 0.32 & 0.22 & 0.30 \\
\hline$\alpha$-Bulnesene & 27.16 & 1507 & 5.68 & 4.24 & 4.96 & 2.03 & 5.45 & 5.14 & 1.55 & 1.96 \\
\hline$\gamma$-Cadinene & 27.49 & 1513 & 4.20 & 3.70 & 3.95 & 1.56 & 2.99 & 2.95 & 2.63 & 3.38 \\
\hline$\delta$-Kadinene & 27.80 & 1524 & 0.39 & 0.39 & 0.39 & - & 0.27 & 0.24 & - & - \\
\hline 1.10-di-epi-Cubenole & 31.36 & 1621 & 0.71 & 0.93 & 0.82 & 0.35 & 0.57 & 0.50 & 0.71 & 0.71 \\
\hline tau-Cadinol & 32.31 & 1646 & $9.80^{\mathrm{Aa}}$ & $10.38^{\mathrm{Aa}}$ & $10.09^{\mathrm{Aa}}$ & $5.63^{\mathrm{Ba}}$ & $8.74^{\mathrm{Ab}}$ & $7.91 \mathrm{Ab}$ & $11.58^{\mathrm{Aa}}$ & $10.9^{\mathrm{Aa}}$ \\
\hline a-Cadinol & 32.77 & 1658 & 0.28 & 0.37 & 0.33 & - & - & - & - & 0.22 \\
\hline Total identified & & & 98.57 & 98.44 & 98.54 & 100.00 & 100.00 & 99.52 & 99.79 & 99.99 \\
\hline Monoterpenes & & & 0.60 & 0.91 & 0.76 & - & - & - & - & - \\
\hline $\begin{array}{l}\text { Oxygenated } \\
\text { monoterpenes }\end{array}$ & & & 64.50 & 65.90 & 65.21 & 87.89 & 73.14 & 73.94 & 77.89 & 78.14 \\
\hline Sesquiterpenes & & & 21.56 & 17.87 & 19.73 & 6.13 & 16.43 & 15.16 & 8.43 & 10.02 \\
\hline $\begin{array}{l}\text { Oxygenated } \\
\text { sesquiterpenes }\end{array}$ & & & 10.79 & 11.68 & 11.24 & 5.98 & 9.31 & 8.41 & 12.29 & 11.83 \\
\hline Phenylpropenes & & & 1.12 & 2.08 & 1.60 & - & 1.12 & 2.01 & 1.18 & - \\
\hline
\end{tabular}

RT - retention time. LRI - linear retention index relative to C9-C23 n-alkanes on a HP-5MS capillary column, W - watered, C - control. Lower case letters in rows represent significant differences between cultivars in the same treatment and capital letters in rows represent significant differences between treatments at the same cultivar, according to the Tukey test at $\alpha=0.05$

Table 6.

The effect of water supply on the HS-SPME composition of sweet basil cultivars (Budapest 2009)

\begin{tabular}{|c|c|c|c|c|c|c|c|c|c|c|}
\hline \multirow{3}{*}{ Component } & \multirow{3}{*}{ RT } & \multirow{3}{*}{ LRI } & \multicolumn{8}{|c|}{ Headspace } \\
\hline & & & \multicolumn{2}{|c|}{ 'Genovese' } & \multicolumn{2}{|c|}{ 'Kasia' } & \multicolumn{2}{|c|}{ 'Keskenylevelü' } & \multicolumn{2}{|c|}{ 'Wala' } \\
\hline & & & W & $\mathrm{C}$ & W & $\mathrm{C}$ & W & $\mathrm{C}$ & $\mathrm{W}$ & $\mathrm{C}$ \\
\hline$\alpha$-Pinene & 5.48 & 935 & 0.87 & 0.94 & - & - & - & - & - & 0.30 \\
\hline Sabinene & 6.52 & 976 & 0.75 & 0.74 & - & - & 0.41 & - & 0.20 & 0.39 \\
\hline$\beta$-Pinene & 6.64 & 981 & 1.45 & 1.51 & - & - & - & - & 0.43 & 0.77 \\
\hline$\beta$-Myrcene & 6.99 & 995 & 1.13 & 1.06 & 0.68 & - & - & - & - & 0.27 \\
\hline Limonene & 8.19 & 1031 & 1.18 & 1.41 & 0.21 & - & 0.58 & - & - & 0.33 \\
\hline
\end{tabular}


Table 6. (continued)

\begin{tabular}{|c|c|c|c|c|c|c|c|c|c|c|}
\hline \multirow{3}{*}{ Component } & \multirow{3}{*}{$\mathrm{RT}$} & \multirow{3}{*}{ LRI } & \multicolumn{8}{|c|}{ Headspace } \\
\hline & & & \multicolumn{2}{|c|}{ 'Genovese' } & \multicolumn{2}{|c|}{ 'Kasia’ } & \multicolumn{2}{|c|}{ 'Keskenylevelü' } & \multicolumn{2}{|c|}{ 'Wala' } \\
\hline & & & $\mathrm{W}$ & $\mathrm{C}$ & W & $\mathrm{C}$ & W & $\mathrm{C}$ & $\mathrm{W}$ & $\mathrm{C}$ \\
\hline 1,8-Cineole & 8.77 & 1048 & $10.93^{\mathrm{Aa}}$ & $12.33^{\mathrm{Aa}}$ & $0.10^{\mathrm{Ad}}$ & $0.61^{\text {Ad }}$ & $4.88^{\mathrm{Ac}}$ & $1.06^{\mathrm{Ac}}$ & $6.00^{\mathrm{Ab}}$ & $7.10^{\mathrm{Ab}}$ \\
\hline (E)-Ocimene & 8.85 & 1050 & 6.37 & 5.42 & 0.77 & - & 1.89 & 1.17 & - & 0.51 \\
\hline Terpinolene & 10.29 & 1092 & 1.07 & 1.42 & 0.20 & - & 0.56 & - & - & - \\
\hline Linalool & 11.17 & 1112 & $49.66^{\mathrm{Ab}}$ & $54.40^{\mathrm{Ab}}$ & $73.99^{\mathrm{Aa}}$ & $72.92^{\mathrm{Aa}}$ & $67.66^{\mathrm{Aa}}$ & $67.35^{\mathrm{Aa}}$ & $63.24^{\mathrm{Aa}}$ & $68.15^{\mathrm{Aa}}$ \\
\hline Camphor & 13.1 & 1151 & 0.28 & 0.50 & 0.50 & - & - & - & - & - \\
\hline Terpinen-4-ol & 14.21 & 1174 & - & - & - & - & - & - & 0.75 & - \\
\hline Linalyl acetate & 17.65 & 1269 & - & - & 0.89 & - & - & - & 2.89 & 2.23 \\
\hline Isobornyl acetate & 18.64 & 1300 & 0.63 & - & - & - & - & - & - & - \\
\hline$\alpha$-Cubebene & 21.08 & 1359 & 0.28 & - & 0.25 & - & 0.27 & - & 0.58 & 0.32 \\
\hline Eugenol & 21.67 & 1373 & 0.89 & - & - & - & 0.52 & 1.04 & - & - \\
\hline$\alpha$-Copaene & 22.03 & 1382 & 0.70 & 0.40 & 0.68 & - & 0.90 & 1.27 & 0.36 & 0.46 \\
\hline$\beta$-Elemene & 22.65 & 1397 & 4.30 & 4.43 & 4.91 & 6.74 & 5.17 & 5.90 & 6.18 & 3.14 \\
\hline$\beta$-Caryophyllene & 23.68 & 1423 & 0.38 & - & 0.29 & 1.17 & 0.30 & 0.42 & - & - \\
\hline $\begin{array}{l}\text { trans }-\alpha- \\
\text { Bergamotene }\end{array}$ & 24.36 & 1440 & 0.45 & 0.41 & 0.35 & - & 0.48 & 1.26 & 0.40 & 0.24 \\
\hline$\alpha$-Guaiene & 24.45 & 1442 & 2.81 & 2.60 & 2.92 & 2.90 & 3.78 & 4.40 & 2.97 & 1.51 \\
\hline$\alpha$-Humulene & 25.07 & 1458 & 0.66 & 0.73 & 0.37 & 0.49 & 0.62 & 0.87 & 0.33 & - \\
\hline$\beta$-Cubebene & 25.42 & 1467 & 0.58 & & 0.65 & 0.59 & 0.57 & 0.65 & 0.81 & 0.70 \\
\hline Germacren-D & 26.18 & 1486 & $6.60^{\mathrm{Aa}}$ & $5.20^{\mathrm{Aa}}$ & $5.28^{\mathrm{Aa}}$ & $6.03^{\mathrm{Aa}}$ & $5.06^{\mathrm{Aa}}$ & $6.53^{\mathrm{Aa}}$ & $6.06^{\mathrm{Aa}}$ & $5.86^{\mathrm{Aa}}$ \\
\hline$\beta$-Selinene & 26.38 & 1491 & - & - & - & - & - & - & - & 1.03 \\
\hline Bicyclogermacrene & 26.81 & 1501 & 1.64 & 1.45 & 0.91 & 0.98 & 1.37 & 1.54 & - & - \\
\hline$\alpha$-Bulnesene & 27.16 & 1507 & 3.41 & 3.10 & 3.30 & 4.15 & 3.30 & 4.32 & 4.21 & 2.18 \\
\hline$\gamma$-Cadinene & 27.49 & 1513 & 1.73 & 1.50 & 2.39 & 3.31 & 1.67 & 1.91 & 4.40 & 3.89 \\
\hline Total identified & & & 99.08 & 100.00 & 99.49 & 99.88 & 99.96 & 99.67 & 99.78 & 99.36 \\
\hline Monoterpenes & & & 13.18 & 12.96 & 1.85 & - & 3.44 & 1.17 & 0.63 & 2.57 \\
\hline $\begin{array}{l}\text { Oxygenated } \\
\text { monoterpenes }\end{array}$ & & & 61.50 & 67.23 & 75.37 & 73.53 & 72.54 & 68.41 & 72.88 & 77.47 \\
\hline Sesquiterpenes & & & 23.52 & 19.82 & 22.27 & 26.36 & 23.47 & 29.05 & 26.28 & 19.32 \\
\hline $\begin{array}{l}\text { Oxygenated } \\
\text { sesquiterpenes }\end{array}$ & & & - & - & - & - & - & - & - & - \\
\hline Phenylpropenes & & & 0.89 & - & - & - & 0.52 & 1.04 & - & - \\
\hline
\end{tabular}

RT - retention time. LRI - linear retention index relative to C9-C23 n-alkanes on a HP-5MS capillary column, W - watered, C - control. Lower case letters in rows represent significant differences between cultivars in the same treatment and capital letters in rows represent significant differences between treatments at the same cultivar, according to the Tukey test at $\alpha=0.05$

\section{DISCUSSION}

In last few years, several papers have been published about the effect of irrigation or its opposite, drought stress. However, until now the intraspecific sensitivity of species was tested only as an exception. In current experiment, the non-irrigated control treatment may represent drought stress, because during the vegetation period, less than $200 \mathrm{~mm}$ natural precipitation fell, while the watered plants got an extra $500 \mathrm{~mm}$. This difference of water dosages had an easily detectable effect on most of investigated parameters. Due to the higher stomatal conductivity induced by better water supply, the basil plants could raise their assimilation activity.

We found higher SPAD units due to the drought. The same findings were reported earlier [7, 22]. Nevertheless, it is rarely highlighted that the SPAD 
value is based on the light absorbance of leaves and thus turgor, leaf thickness or leaf hairiness might influence the results. Higher SPAD value does not necessarily mean an increase in chlorophyll content.

In basil, reduction of stomatal conductance was found as a response to salinity stress conditions [23], which have an effect similar to that of water stress. Drought stress might trigger the closure of stomata. While the uptake of $\mathrm{CO}_{2}$ is blocked, the biosynthesis may shift in the direction of secondary metabolites and in parallel, the biomass production is most frequently reduced $[22,24]$. On the other side, a better water supply was realized in significantly higher biomass and $\mathrm{EO}$ yields with only smaller differences among cultivars. For the agricultural practice, the double yield may be important, even if costs would also increase due to the irrigation.

As mentioned above, water shortage may enhance the accumulation level of secondary metabolites. In the current experiment, this could not be adequately supported. The majority of the cultivars reacted to the better water supply with lower EO accumulation levels. At the same time, it must be recognized that the EO yield depends mainly on the biomass production: under the circumstances of the experiment, the slight increase of EO concentration due to the drought could not compensate for the significant loss of biomass. All investigated cultivars showed higher EO yield under irrigation. No correlation was found between the glandular hair density and essential oil content $(\mathrm{R}=0.160, p=0.760)$, thus, the higher glandular hair density does not mean necessarily higher essential oil content. Unfortunately, glandular hair density itself is not sufficient to predict the EO content or yield of the cultivated basil plants.

Based on EO composition, all cultivars belong to the linalool chemotype, also with higher ratios of linalyl-acetate (8.7-11.3\%) in two Polish cultivars. As for the effect of irrigation on the EO composition, previous data are contradictory. The authors of [12] reported an increase of the absolute quantities of estragole (from 0.9 to $4.0 \mu \mathrm{l} \mathrm{g}^{-1}$ ) and linalool (from 0.8 to $\left.1.0 \mu \mathrm{l} \mathrm{g}^{-1}\right)$. In our earlier study under controlled conditions, the water shortage decreased the linalool ratio of sweet basil [7] while Khalid [13] and Ekren et al. [16] could not detect significant changes in the oil spectrum resulting from the water supply. In the present experiment, the role of the intraspecific cultivar was established; compositional changes were registered only in the cultivar 'Kasia' for linalool, 1,8 cineole and tau-cadinol ratios. Based on the present data, the HS did not change significantly due to the irrigation treatment, which might be in connection with the higher boiling point and molecular weight affecting the volatility of compounds as mentioned also by [25].

\section{CONCLUSION}

We can conclude that irrigation increases the biomass and EO yield of basil, while the composition of $\mathrm{EO}$ is mostly unchanged. The reaction of the plants to irrigation was significantly influenced by the specific cultivar in the case of EO content. In this study, the responses of the Polish cultivar 'Kasia' showed the largest differences, as compared to others. For the cultivation practice, it would be important to be aware of the special intraspecific requirements of the cultivars.

\section{ACKNOWLEDGEMENTS}

This research was supported by the EU-Erasmus+ EOHUB project (600873-EPP-1-2018-1ES-EPPKA2-KA) and the Ministry for Innovation and Technology within the framework of the Thematic Excellence Programme 2020- Institutional Excellence Subprogram (TKP2020-IKA-12) for research on plant breeding and plant protection.

Conflict of interest: Authors declare no conflict of interest.

\section{REFERENCES}

1. Johnson CB, Kirby J, Naxakis G, Pearson S. Substantial UV-B-mediated induction of essential oils in sweet basil (Ocimum basilicum L.). Phytochemistry 1999; 51:507-510. doi: https://dx.doi. org/10.1016/S0031-9422(98)00767-5

2. Telci I, Bayram E, Yılmaz G, Avcı B. Variability in essential oil composition of Turkish basils (Ocimum basilicum L.). Biochem Syst Ecol 2006; 34:489-497. doi: https://dx.doi.org/10.1016/j. bse.2006.01.009

3. Hiltunen R, Holm Y. Essential oil of Ocimum. In: Hiltunen R, Holm Y (eds.). Basil - the genus Ocimum. Taylor \& Francis e-Library; 2006:77-111.

4. Grayer RJ, Kite GC, Goldstone FJ, Bryan SE, Paton A, Putievsky E. Infraspecific taxonomy and essential oil chemotypes in sweet basil, Oci- 
mum basilicum. Phytochemistry 1996;43:10331039. doi: https://dx.doi.org/10.1016/S00319422(96)00429-3

5. Carović-Stanko K, Orlić S, Politeo O, Strikić F, Kolak I, Milos M, et al. Composition and antibacterial activities of essential oils of seven Ocimum taxa. Food Chem 2010; 119:196-201. doi: https:// dx.doi.org/10.1016/j.foodchem.2009.06.010

6. De Masi L, Siviero P, Esposito C, Castaldo D, Siano F, Laratta B. Assessment of agronomic, chemical and genetic variability in common basil (Ocimum basilicum L.). Eur Food Res Technol 2006; 223:273-281. doi: https://dx.doi.org/10.1007/ s00217-005-0201-0

7. Radácsi P, Inotai K, Sárosi S, Czövek P, Bernáth J, Németh É. Effect of water supply on the physiological characteristic and production of basil (Ocimum basilicum L.). Eur J Hortic Sci 2010; 75:193-197.

8. Dzida K. Biological value and essential oil content in sweet basil (Ocimum basilicum L.) depending on calcium fertilization and cultivar. Acta Sci PolHortoru 2010; 9:153-161.

9. Nurzyńska-Wierdak R. Sweet basil essential oil composition: relationship between cultivar, foliar feeding with nitrogen and oil content. J Essent Oil Res 2012; 24:217-227. doi: https://dx.doi.org/10.1 080/10412905.2012.676763

10. Gershenzon J, Lincoln DE, Langenheim JH. The effect of moisture stress on monoterpenoid yield and composition in Satureja douglasii. Biochem Syst Ecol 1978; 6:33-43. doi: https://dx.doi. org/10.1016/0305-1978(78)90022-4

11. Misra A, Srivastava NK. Influence of water stress on japanese mint. J Herbs Spices Med Plants 2000; 7:51-58. doi: https://dx.doi.org/10.1300/ J044v07n01_07

12. Simon JE, Reiss-Bubenheim D, Joly RJ, Charles DJ. Water stress-induced alterations in essential oil content and composition of sweet basil. J Essent Oil Res Research 1992; 4:71-75. doi: https:// dx.doi.org/10.1080/10412905.1992.9698013

13. Khalid KA. Influence of water stress on growth, essential oil, and chemical composition of herbs (Ocimum sp.). Int Agrophys 2006; 20:289-296.
14. Khalil SE, Nahed G. Abd El- Aziz, Bedour H. Abou Leila. Effect of water stress, ascorbic acid and spraying time on some morphological and biochemical composition of Ocimum basilicum plant. J Am Sci 2010; 6:33-44.

15. Ade-Ademilua EO, Obi HO, Craker LE. Growth and essential oil yield of african basil, Ocimum gratissimum, under light and water stress. JMAP 2013; 1:143-149.

16. Ekren S, Sönmez Ç, Özçakal E, Kurttaş YSK, Bayram E, Gürgülü $H$. The effect of different irrigation water levels on yield and quality characteristics of purple basil (Ocimum basilicum L.). Agr Water Manag 2012; 109:155-161. doi: https:// dx.doi.org/10.1016/j.agwat.2012.03.004

17. Radácsi P, Inotai K, Sárosi S, Nérneth É. Effect of soil water content on the physiological parameters, production and active substances of summer savory (Satureja hortensis L.). Acta Scientiarum Polonorum Hortorum Cultus 2016; 15(2):3-12.

18. Radácsi P, Sárosi S, Szomor LÁ, Németh-Zámbori É. Comparison of the production and chemical constituents of five Perilla frutescens (L.) Britt. accessions. Acta Biol Hung 2017; 68:453-465. doi: https://dx.doi.org/10.1556/018.68.2017.4.10

19. Pharmacopoeia Hungarica. Pharmacopoeia Hungarica 7th ed., vol. 1, Budapest: 1986:395398.

20. Radácsi P, Inotai K, Rajhárt P, Sárosi S, NémethZámboriné É. Effect of irrigation on the production and secondary Metabolites of summer savory (Satureja hortensis L. 'Budakalászi'). Agric Conspec Sci 2019; 84:4.

21. van Den Dool H, Kratz DP. A generalization of the retention index system including linear temperature programmed gas-liquid partition chromatography. J Chromatogr A 1963; 11:463-1. doi: https://dxdoi.org/10.1016/S00219673(01)80947-X

22. Al-Gabbiesh A, Kleinwächter M, Selmar D. Influencing the contents of secondary metabolites in spice and medicinal plants by deliberately applying drought stress during their cultivation. Jordan J Biol Sci 2015; 147:1-10. doi: https://dx.doi. org/10.12816/0026941 
23. Attia H, Ouhibi C, Ellili A, Msilini N, Bouzaïen G, Karray N, et al. Analysis of salinity effects on basil leaf surface area, photosynthetic activity, and growth. Acta Physiol Plant 2011; 33:823-833. doi: https://dx.doi.org/10.1007/s11738-010-0607-6

24. Selmar D, Kleinwächter M. Stress enhances the synthesis of secondary plant products: the impact of stress-related over-reduction on the accumulation of natural products. Plant Cell Physiol 2013; 54:817-826. doi: https://dx.doi.org/10.1093/pcp/ pct054
25. da Silva CE de L, da Costa WF, Minguzzi S, da Silva RC de L, Simionatto E. Assessment of volatile chemical composition of the essential oil of Jatropha ribifolia (Pohl) Baill by HS-SPMEGC-MS using different fibers. J Anal Methods Chem 2013; 2013:1-8. doi: https://dx.doi. org/10.1155/2013/352606 